\title{
Gambaran tumpatan glass ionomer cement pada mahasiswa akademi keperawatan rumah sakit tingkat III Robert wolter monginsidi
}

\author{
${ }^{1}$ Rudy Hakim, ${ }^{2}$ dr.B.lampus,M.Kes PKK, ${ }^{3}$ drg. Vonny N. S. Wowor, M.Kes \\ ${ }^{1}$ Mahasiswa Program Studi Kedokteran Gigi Fakultas Kedokteran Universitas Sam Ratulangi \\ ${ }^{2}$ Fakultas Kedokteran Universitas Sam Ratulangi \\ ${ }^{3}$ Program Studi Kedokteran Gigi Fakultas Kedokteran Universitas Sam Ratulangi
}

\begin{abstract}
ABSTRAK
Kesehatan gigi dan mulut merupakan salah satu faktor penting dalam mencegah timbulnya penyakit di dalam tubuh. Salah satu masalah kesehatan gigi dan mulut yaitu karies. Salah satu cara penanggulangan karies adalah dengan membuang jaringan karies dan menumpatnya dengan bahan restorasi. Bahan restorasi berfungsi untuk memperbaiki dan merestorasi struktur gigi yang rusak. Saat ini pasien dan dokter gigi mempunyai banyak pilihan yang bervariasi dalam memilih material dan prosedur untuk merestorasi gigi yang berlubang akibat karies. Material-material restorasi yang digunakan yaitu amalgam, komposit dan glass ionomer kaca.

Penelitian ini merupakan penelitian deskriptif. Penelitian dilakukan di AKPER Rumkit TK. III TNI-AD R. W Monginsidi Manado. Populasi pada penelitian ini yaitu seluruh mahasiswa AKPER Rumkit TK. III TNI-AD R. W Monginsidi Manado yang berjumlah 315 mahasiswa. Sampel penelitian yaitu mahasiswa yang menggunakan tumpatan GIC dengan total populasi yang berjumlah 83 mahasiswa.

Hasil pemeriksaan menunjukkan bahwa penggunaan tumpatan GIC pada mahasiswa AKPER yang paling banyak yaitu wanita dengan alasan pemilihan bahan tumpatan sesuai anjuran dokter gigi. Sebagian besar tumpatan GIC yang mengalami ketidakutuhan berusia 1 sampai 6 bulan karena dipakai mengunyah makanan keras yang di tumpat kurang dari 24 jam.
\end{abstract}

Kata kunci: Karies, tumpatan, glass ionomer kaca.

\begin{abstract}
Oral health is an important factor in preventing the onset of disease in the body. One of the problems of oral health is caries. One way to resolve this problem is by removing the caries prevention of caries and restore the tissue with restorative material. Restorative materials and restoration works to improve the damaged tooth structure. Currently, the patient and the dentist have a lot of options that vary in selecting materials and procedures for the restoration of dental cavities caused by caries. Restoration materials used are amalgam, composite and glass ionomer cement.

This is a descriptive study. This study was conducted in the Army Nursing Academy Hospital TK.III R. W Monginsidi Manado. The population in this study is all the students of Army Nursing Academy Hospital TK.III R. W Monginsidi Manado, amounting to 315 students. Sample of this study is students who use dental restorative material GIC with a total population of 83 students.

The highest number of sample wuth dental restorative material GIC in Nursing Academy students is women with the reasons of selection of materials as recommended by dentist. Most of which have damage of GIC 1 to 6 months old that used in chewing hard foods that are less than 24 hours.
\end{abstract}

Keyword: Caries, dental restorative material, Glass ionomer Cement.

Korespondensi: Rudy Hakim, Mahasiswa Program Studi Kedokteran Gigi Fakultas Kedokteran Universitas Sam Ratulangi Manado, Email: rhakim29@rocketmail.com

\section{PENDAHULUAN}

Kesehatan gigi dan mulut merupakan salah satu faktor penting dalam mencegah timbulnya penyakit di dalam tubuh. Kurangnya kesadaran dan pengetahuan masyarakat tentang kesehatan gigi dan mulut, serta mahalnya biaya perawatan gigi antara lain merupakan penyebab banyaknya masalah gigi dan mulut yang ditemukan pada masyarakat. Masalah kesehatan gigi dan mulut yang paling sering ditemui yaitu karies. Karies adalah penyakit jaringan keras gigi yang disebabkan oleh aktivitas mikroorganisme yang ditandai dengan terjadinya demineralisasi jaringan email yang disertai dengan kerusakan jaringan organiknya. Berdasarkan laporan Zero pada tahun 2009 di Amerika, sekitar $90 \%$ karies terdapat pada pit dan fissur gigi permanen posterior dan merupakan gigi yang paling rentan terhadap karies. Karies merupakan penyebab penyakit 
gigi dengan prevalensi tertinggi di Indonesia. ${ }^{1}$ Hasil Riset Kesehatan Dasar (RISKESDAS) pada tahun 2007, menunjukkan bahwa prevalensi penduduk yang memiliki masalah kesehatan gigi dan mulut terdapat pada kelompok usia 15-24 tahun yaitu memiliki karies sebesar $41,2 \%$ dan melakukan perawatan sebesar 26,5\%, serta merupakan kelompok usia terbanyak yang menumpat gigi. Berdasarkan data hasil RISKESDAS, provinsi Sulawesi Utara merupakan salah satu dari 5 provinsi yang memiliki nilai tertinggi dalam masalah kesehatan gigi dan mulut yaitu $29,8 \%$. $^{2,3}$

Salah satu penanggulangan karies adalah dengan membuang jaringan karies dan menumpatnya dengan bahan restorasi. Bahan restorasi berfungsi untuk memperbaiki dan merestorasi struktur gigi yang rusak. Saat ini pasien dan dokter gigi mempunyai banyak pilihan yang bervariasi dalam memilih material dan prosedur untuk merestorasi gigi yang berlubang akibat karies. Bahan restorasi yang digunakan yaitu amalgam, komposit dan glass ionomer cement. ${ }^{4}$.

Amalgam merupakan campuran dari beberapa logam dan merkuri. Amalgam digunakan sebagai bahan tumpatan gigi posterior karena dapat menahan tekanan kunyah dan tidak mudah fraktur. Komposit merupakan bahan tumpatan estetik yang dapat digunakan pada gigi anterior dan posterior, memiliki kemampuan mengiritasi pulpa yang cukup rendah, serta memiliki ketahanan terhadap celah mikro (microleakage) yang terbentuk di antara bahan tumpatan dengan struktur gigi. Glass ionomer cement (GIC) merupakan salah satu bahan restorasi estetik yang digunakan pada gigi anterior dan posterior, bersifat adhesif terhadap jaringan gigi dengan perlekatan struktur gigi dan aplikasinya mudah serta mengandung fluor untuk mencegah karies sekunder., ${ }^{4,5}$

Masing-masing jenis bahan tambal memiliki keunggulan, namun masyarakat Indonesia pada umumnya lebih memilih amalgam dan GIC karena harganya yang relatif murah dibandingkan dengan bahan tumpatan komposit. Apabila dibandingkan dengan amalgam, GIC lebih unggul dari segi estetik dan nilai ekonomisnya.

Mahasiswa Akademik Keperawatan (Akper) Rumah Sakit TK. III TNI-AD Robert Wolter Monginsidi Manado mempunyai kekhususan, yakni mereka diasramakan selama menempuh pendidikan. Hal ini memudahkan penulis dalam menjangkau populasi ini. Pada survei awal yang dilakukan, penulis menemukan banyaknya mahasiswa yang memiliki tumpatan GIC pada giginya. Keadaan ini yang membuat penulis tertarik untuk melakukan penelitian tentang kondisi bahan tumpatan ini pada mahasiswa Akper tersebut di atas. Ketiadaan data statistik tentang tumpatan GIC ini serta dari aspek keterjangkauan menjadi alasan penulis memilih populasi ini untuk diteliti.

\section{METODE PENELITIAN}

Penelitian ini merupakan penelitian deskriptif dengan menggunakan metode total sampling. Penelitian dilaksanakan di AKPER Rumkit TK. III R. W. Monginsidi Manado pada bulan Februari 2012, Populasi pada penelitian ini yaitu seluruh mahasiswa AKPER Rumkit TK. III TNI-AD R. W Monginsidi Manado yang berjumlah 315 mahasiswa, Sampel penelitian yaitu mahasiswa yang menggunakan tumpatan GIC. Metode pengambilan sampel yang digunakan adalah total populasi yang berjumlah 83 mahasiswa. Kriteria inklusi terdaftar sebagai mahasiswa akper rumkit tk. III TNI-AD R.W Monginsidi Manado. Memiliki tumpatan GIC, bersedia dengan sukarela di jadikan sebagai subyek dalam penelitian ini, bersifat kooperatif selama pengambilan data, berada ditempat saat proses pengambilan data.

Kriteria eksklusi, Tidak terdaftar sebagai mahasiswa AKPER. III TNI-AD R. W Monginsidi Manado, Tidak bersedia menjadi subjek penelitian, Tidak hadir pada saat dilakukan proses penelitian. Variabel penelitian, Tumpatan GIC. Alasan pemilihan tumpatan GIC. Jenis kelamin, Keutuhan GIC,Usia tumpatan,Waktu terjadinya ketidakutuhan tumpatan ,Penyebab ketidakutuhan tumpatan.

Definisi operasional, GIC adalah water based cement, yang terbentuk dari reaksi asam basa antara bubuk fluoroaluminosilikat glass (base) dan larutan poliasam (liquid), Jenis kelamin, laki-laki atau perempuan, Keutuhan GIC, secara klinis terlihat utuh tidaknya suatu tumpatan, Usia tumpatan GIC yaitu lamanya penggunaan tumpatan GIC, Ketidakutuhan tumpatan GIC, Waktu terjadinya ketidakutuhan tumpatan GIC. Instrumen penelitian, Kaca mulut untuk memudahkan dalam mengobservasi rongga mulut, Senter untuk memudahkan lapangan pandang yang jelas, Formulir wawancara untuk 
mencatat hasil pemeriksaan dan hasil wawancara, Alat tulis menulis untuk menulis hasil wawancara responden, Alat dan bahan untuk sterilisasi kaca mulut yaitu baskom, air, deterjen, sikat kecil, bayclin, panci, dan kompor. Pelaksanaan dan pengambilan data, pertimbangan etik Izin penelitian dimintakan pada AKPER RUMKIT TK III TNI-AD R. W Monginsidi, di mana mahasiswa yang memiliki tumpatan GIC akan dilakukan pemeriksaan klinis dan informed consent

Pengambilan data penelitian diperoleh dengan memeriksa tumpatan GIC yang digunakan. Data yang dikumpulkan meliputi jenis kelamin, lama penggunaan tumpatan, dan alasan menggunakan GIC

Data diolah dan dianalisis berdasarkan distribusi frekuensi dalam bentuk tabel dan diagram atau grafik kemudian dianalisis berdasarkan hasil persentase.

\section{PEMBAHASAN}

Berdasarkan hasil pemeriksaan terhadap subyek penelitian yang paling banyak mendapatkan tumpatan GIC yaitu pada wanita sebesar 46 orang (55\%) dibandingkan pria sebesar 37 (45\%). Hal ini dikarenakan wanita lebih memerhatikan penampilan estetik serta memiliki kesadaran untuk menjaga kebersihan gigi dan mulut dibandingkan pria. Hasil penelitian ini, sama halnya dengan penelitian yang dilakukan oleh Jeniffer Ann Soncini di New England terhadap 205 pasien yang ditumpat dengan GIC yaitu pada pasien wanita yang paling banyak menggunakan tumpatan GIC sebesar $35,8 \%$ dibandingkan pasien laki-laki sebesar 22,6\%. ${ }^{18}$ Pasien wanita lebih mementingkan prinsip dan nilai estetik, di mana wanita sering melakukan tindakan profilaksis (pencegahan) yang disarankan oleh dokter gigi. ${ }^{20}$

Berdasarkan hasil pemeriksaan terhadap subyek penelitian dengan alasan penumpatan GIC yaitu paling banyak menggunakan tumpatan GIC karena anjuran dokter sebesar 56 orang $(68 \%)$ dibandingkan dengan alasan kuatnya bahan restorasi GIC. GIC merupakan salah satu bahan restorasi yang banyak digunakan di rumah sakit, puskesmas maupun klinik dokter gigi di kota Manado. GIC digunakan untuk memperbaiki kerusakan pada gigi seperti fraktur, karies, dan perbaikan estetik sebagian besar artikel menargetkan dokter gigi umum difokuskan pada prosedur estetik dan bahan. Jurnal yang dikhususkan untuk estetika gigi kini telah menjadi bagian dari sirkulasi reguler publikasi untuk dokter gigi di seluruh dunia sehingga dokter gigi sering menganjurkan pemakaian restorasi estetik dengan menggunakan bahan GIC. ${ }^{15}$

Berdasarkan hasil pemeriksaan terhadap subyek penelitian dilihat dari keutuhan tumpatan yaitu paling banyak didapatkan tumpatan yang tidak utuh sebanyak 76 tumpatan (64\%) dibandingkan dengan tumpatan yang utuh sebanyak 42 tumpatan (36\%). Hal ini menjelaskan beberapa kelemahan dari GIC antara lain koefisien thermal ekspansi yang rendah, dapat mengurangi demineralisasi, mudah pecah dan rentan terhadap abrasi. Hasil penelitian ini sama halnya dengan yang dilakukan oleh Mahesh Singh dimana GIC merupakan jenis restorasi yang lebih lemah dibandingkan jenis restorasi gigi lainnya, namun $70 \%$ kerusakan GIC diakibatkan karena kesalahan pemasangan ketimbang kualitas dari GIC tersebut. ${ }^{17}$

Berdasarkan hasil pemeriksaan subyek penelitian dilihat dari usia tumpatan yaitu tumpatan yang paling banyak terdapat pada usia 1 sampai 6 bulan berjumlah 56 tumpatan $48 \%$ dibandingkan dengan usia tumpatan yang di atas 2 tahun sebesar 6 tumpatan (5\%). Dari hasil ini, dapat dilihat rata-rata sampel pada penelitian ini belum lama menggunakan bahan restorasi GIC. Hal ini disebabkan oleh prosedur pencampuran bahan yang kurang tepat atau tidak sesuai prosedur serta ketahanan terhadap daya kunyah sangat rendah. $^{15}$

Berdasarkan hasil pemeriksaan subyek penelitian dilihat dari waktu terjadinya ketidakutuhan tumpatan yaitu paling banyak pada usia tumpatan 1 sampai 6 bulan berjumlah 42 tumpatan (55\%) dibandingkan dengan usia tumpatan di atas 2 tahun berjumlah 4 tumpatan (5\%). Hal ini dikarenakan bahan tumpatan GIC rentan terhadap abrasi, kekuatan lebih rendah dibandingkan dengan resin komposit dan amalgam serta transulensi lebih rendah dari resin komposit. GIC bersifat rapuh karena mikroporositas dari bahan tersebut cukup tinggi. Hasil pada penelitian ini sejalan dengan penelitian yang dilakukan oleh Roland Frankenberger di Jerman terhadap 80 pasien yang memakai tumpatan GIC, 54 pasien kembali ke dokter gigi karena alasan rusaknya tumpatan 
selama 12 bulan (1 tahun) setelah pemasangan, sedangkan 26 pasien kembali ke dokter gigi setelah 24 bulan ( 2 tahun). ${ }^{7}$

Berdasarkan hasil pemeriksaan subyek penelitian tentang penyebab ketidakutuhan tumpatan GIC yaitu paling banyak tumpatan tidak utuh karena dipakai mengunyah makanan keras setelah ditumpat kurang dari 24 jam sebesar 52 tumpatan $(68 \%)$ dan yang tidak utuh karena dipakai mengunyah makan keras lebih dari 24 jam sebesar 24 tumpatan (32\%). Hal ini dikarenakan pada tiap pabrik pembuatan GIC memberikan instruksi yang berbeda serta pengerasan tumpatan akan terjadi pada waktu yang berlainan. Beberapa produk membutuhkan waktu 24 jam sebelum tumpatan tersebut dapat dipoles dengan baik. Selain itu pencampuran bahan yang tidak sesuai prosedur dan adanya cairan air liur dapat menyebabkan tumpatan terlepas. $^{6}$

\section{KESIMPULAN}

Penggunaan bahan tumpatan GIC pada mahasiswa AKPER yang paling sering pada mahasiswa yang berjenis kelamin wanita dibandingkan dengan mahasiswa pria.

Alasan pemilihan bahan tumpatan GIC paling banyak yakni sesuai anjuran dokter gigi yang merawat.

Sebagian besar keutuhan tumpatan GIC yang terdapat pada mahasiswa AKPER yakni tumpatan tidak utuh lebih banyak ditemukan dari pada tumpatan yang masih utuh.

Sebagian besar tumpatan GIC yang mengalami ketidakutuhan berusia 1 sampai 6 bulan.

Penggunaan tumpatan GIC dilihat dari waktu terjadinya ketidakutuhan paling banyak yaitu pada usia 1 - 6 bulan.

Penyebab ketidakutuhan tumpatan yang didapatkan dari hasil wawancara sebagian besar dikarenakan pengunyahan makanan keras setelah ditumpat kurang dari 24 jam.

\section{SARAN}

Diharapkan adanya edukasi tentang pentingnya menjaga kesehatan gigi dan mulut untuk mencegah adanya kerusakan dan rutin melakukan pemeriksaan gigi dan mulut, Diharapkan adanya edukasi tentang perawatan tumpatan GIC agar tumpatan dapat bertahan lama dalam rongga mulut.

\section{DAFTAR PUSTAKA}

1. Pintauli, Sondang. Menuju gigi dan mulut sehat: pencegahan dan pemeliharaan. Medan: USU Press; 2011.

2. Soendoro T. Laporan Hasil Riset Kesehatan Dasar (RISKESDAS). Badan Penelitian dan Pengembangan Kesehatan Nasional 2007; hal. 130-1. Jakarta. 2008.

3. Zero D, Fontana M, Martinez E, Martinez A, Ferreira A, Ando M, Gonzalez C and Bayne S. The Biology, Prevention, Diagnosis and Treatment of Dental Caries. Scientific Advances in the United States. J Am Dent Assoc [ serial online] 2009 Sept [cited 2011 Nov 3]; 140(1): [25 - 34 S]. Available from: URL:

http://jada.ada.org/content/140/suppl_1/25S.a bstract.

4. Irawan B. Material Restorasi Direk Kedokteran Gigi Saat Ini. J. Dentistry Indonesia. 2004; 11(1): 24-8

5. Christensen JG. Direct Restorative Materials. J Am Dent Assoc, Oct 2003; 134; p. 1395-7.

6. Baum L, Phillips RW, Lund MR. Buku Ajar Ilmu Konservasi Gigi, alih bahasa Tarigan Rasinta. $3^{\text {th }}$ ed. Jakarta: EGC. 1997. hal. 3005.

7. Anusavice, Kenneth J. Philips: Buku Ajar Ilmu Bahan Kedokteran Gigi, alih bahasa Johan AB dan Susi Purwoko. $10^{\text {th }}$ ed. Jakarta: EGC; 2003. hal. 499

8. McCabe JF, Walls AWG. Applied Dental Materials. $9^{\text {th }}$ ed. Australia: Blackwell; 2008. p. 195-224.

9. ADA Council on Scientific Affairs. Direct and Indirect Restorative Materials. J Am Dent Assoc. 2003; 134; p. 463-72.

10. Kidd EM. Pickard's Manual of Operative Dentistry. $8^{\text {th }}$ ed. London: Oxford University Press.2003. p. 5, 60-6.

11. Turkun LS, Aktener BO. Twenty Four Month Clinical Evaluation of Different Posterior Composite Resin Materials. J Am Dent Assoc. 2001.

12. Chiayi S. Dental Cements. In : Philips Science of Dental Materials. $11^{\text {th }}$ Edition. Missouri ; Elsevier. 2003. p. 477

13. Susana F. Direct Esthetic Adhesive Restorative Materials. AEGIS Denstistry.2006. p. 1. 
14. Curtis R, Watson TF. Woodhead Publishing in Materials: Dental Biomaterial. 2008. p. 183-9.

15. Indriani. Survei Pemaparan Penggunaan Amalgam, GIC dan Resin Komposit sebagai Bahan Tumpatan Gigi di RSGMP FKG UI pada Tahun 2005, 2006 dan 2007. Skripsi (Tidak dipublikasikan); Fakultas Kedokteran Gigi Universitas Indonesia; 2008.

16. Mahesh S .Glass Ionomer Cements (GIC) In Dentistry: A Review. Vol : I. IJPAES. 2011. p.28-9.

17. Craig RG, Powers JM, Wataha JC. Dental Materials: Properties and Manipulation. $8^{\text {th }}$ ed. St. Louis, Missouri: Mosby Company. 2004. p. 64-85.

18. Christensen JG. Direct Restorative Materials. J Am Dent Assoc, Oct 2003; 134; p. 1395-7.

19. Tim Penyusun Rumkit. Profil Umum Rumah Sakit Tingkat III TNI-AD 07. 06. 01 Robert Wolter Mongisidi. Manado. 2011.

20. Brita W, Saskia W, Sebastian S, Andrian K. Pengaruh jenis kelamin terhadap kesehatan rongga mulut. 2010. 